\title{
The Autumn Migration of Thick-billed Murres near Southern Baffin Island and Northern Labrador
}

\author{
CRAIG D. ORR ${ }^{1}$ and RICHARD M.P. WARD ${ }^{2}$
}

\begin{abstract}
Aerial surveys were used to assess the timing and route of the swimming migration of Thick-billed Murres (Uria lomvia) near southern Baffin Island and northern Labrador in the autumn of 1977, 1978 and 1979. Several hundred thousand adults and chicks from six southern Baffin area colonies departed east through Hudson Strait, in the direction of surface currents, in the latter half of August. Most murres from three eastern Hudson Strait colonies were in offshore waters in early September, arrived in the northern Labrador Sea within a few days, and were followed later in September by murres from three western Hudson Strait colonies. From the Labrador Sea, murres go to marine wintering sites around Newfoundland. Murres from a large colony on southeast Baffin Island apparently did not migrate to the Labrador Sea through western Davis Strait; instead, they either migrated through central Davis Strait en route to Newfoundland, or east to west Greenland, which was also the probable destination of many adult murres which flew by a drillship in southwest Davis Strait.
\end{abstract}

Key words: Thick-billed Murre (Uria lomvia), migration, Baffin Island, Davis Strait, Labrador Sea, eastern Canada, colonial seabird

\begin{abstract}
RÉSUMÉ. Des levées aériennes ont été effectués afin d'étudier la période de déplacement et la route de migration par natation des marmettes de Brünnich (Uria lomvia) près du sud de l'île de Baffin et du nord du Labrador, au cours des automnes des années 1977,1978 et 1979. Durant la deuxième moitié du mois d'août, plusieurs centaines de milliers d'adultes et d'oisillons venant de six colonies du sud de la région de Baffin ont nagé vers l'est en employant le détroit d'Hudson, en direction des courants de surface. La plupart des marmettes de trois colonies dans l'est du détroit d'Hudson se trouvaient dans les eaux au large des côtes au début de septembre, sont arrivées dans le nord de la mer du Labrador quelques jours plus tard, et furent suivies vers la fin de septembre par les marmettes de trois colonies venant de l'ouest du détroit d'Hudson. En partant de la mer du Labrador, les marmettes se sont rendues à des sites d'hivernage marins au large des côtes de Terre-Neuve. Les marmettes d'une grande colonie dans le sud-est de l'île de Baffin ne semblent pas avoir fait leur migration à la mer du Labrador en passant par la partie ouest du détroit de Davis; elles ont plutôt emprunté la partie centrale du détroit de Davis en route vers Terre-Neuve, ou encore vers l'est jusqu'à l'ouest du Groënland, région qui fut aussi la destination probable de bon nombre de marmettes adultes qui ont survolé un navire de forage dans le sud-ouest du détroit de Davis.
\end{abstract}

Mots clés: Marmette de Brünnich (Uria lomvia), migration, île de Baffin, détroit Davis, mer du Labrador, est du Canada, oiseau marin vivant en colonie

Traduit pour le journal par Maurice Guibord.

\section{INTRODUCTION}

Thick-billed Murres (Uria lomvia) are the most abundant colonial seabird in eastern Canada despite high mortality in recent years from shooting, oiling and entanglement in gillnets (Tull et al., 1972; Nettleship, 1977; Salomonsen, 1979). Approximately 1.25 million breeding pairs are concentrated in 11 arctic and subarctic colonies (Brown et al., 1975; Gaston, 1980). In the autumn, these murres begin migrating towards their wintering sites by swimming. The chicks fledge before they are capable of sustained flight (Tuck, 1961); post-breeding adults, like Common Murres (U. aalge) (Birkhead and Taylor, 1977), apparently molt primary feathers at this time, so are also flightless (Fig. 1).

Gaston (1980) summarized the migration patterns of Canadian Thick-billed Murres. Post-breeding adults and their chicks (an average of 0.7 per pair; Gaston and Nettleship, 1981) from Lancaster Sound colonies (northern Baffin Island) cross Baffin Bay to West Greenland in September. Some then travel to marine wintering sites around Newfoundland (Salomonsen, 1950, 1967). Adults and chicks from the six Hudson Strait colonies (Fig. 2), which contain an estimated 665000 breeding pairs (Brown et al., 1975; Gaston, 1980), apparently go to the Labrador

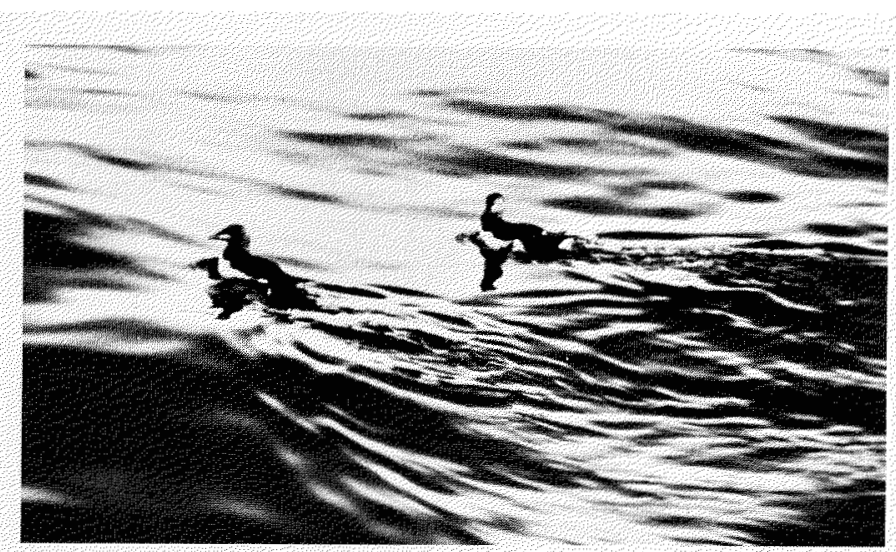

FIG 1. Two adult Thick-billed Murres, each closely followed by a chick, migrating from Hantzsch Island in August 1977 Photo J Booth.

Sea en route to marine sites around Newfoundland. No data are available on the route and destination of murres from a large colony (200 000 pairs) located at Reid Bay on southeast Baffin Island (Fig. 2-E). Additional information on migration routes and timing of these southern Baffin area colonies was required by Canadian regulatory agencies for granting permits for offshore oil exploration and production. This was the purpose of our study.

\footnotetext{
${ }^{1,2}$ MacLaren Plansearch Ltd., 1000 Windmill Road, Dartmouth, Nova Scotia, Canada B3B 1L7

${ }^{1}$ Present address: Department of Biological Sciences, Simon Fraser University, Burnaby, British Columbia, Canada V5A 1S6

${ }^{2}$ Present address: Department of Zoology, University of British Columbia, 6270 University Boulevard, Vancouver, British Columbia,

Canada V6T 2A9
} 


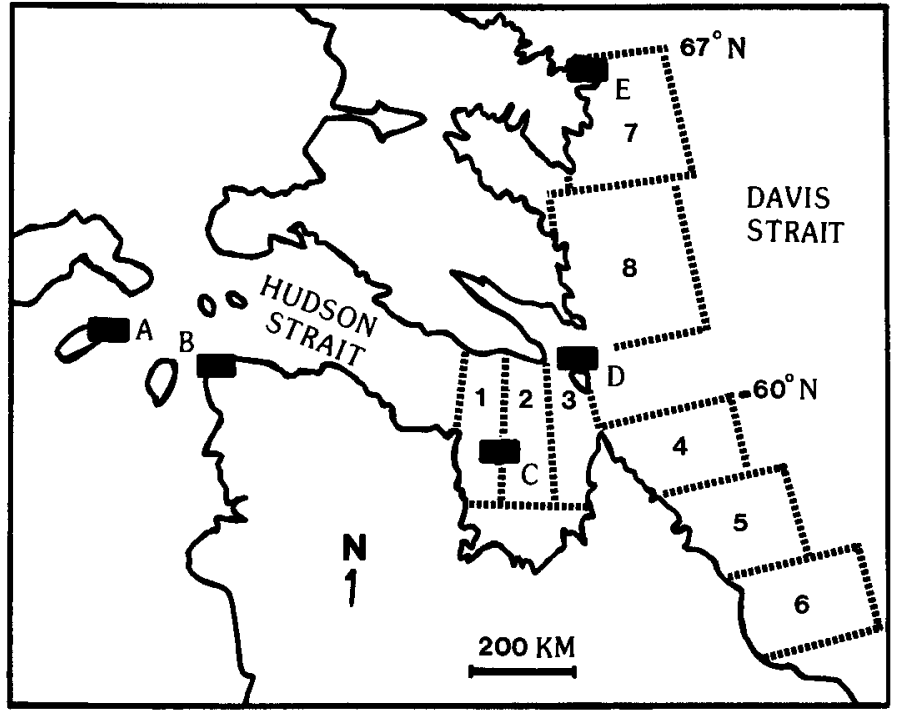

FIG. 2. Locations (dark rectangles) and sizes of Thick-billed Murre colonies near southern Baffin Island (Brown et al., 1975; Gaston, 1980): A-Coats Island, 15000 pairs (p); B-Digges Sound ( 2 colonies), 300000 p; C-Akpatok Island (2 colonies), 300000 p; D-Hantzsch Island, 50000 p; E-Reid Bay, $200000 \mathrm{p}$. Six subdivisions of Hudson Strait and the Labrador Sea (Regions 1-6), and northwest (Region 7) and west-central (Region 8) Davis Strait are also shown.

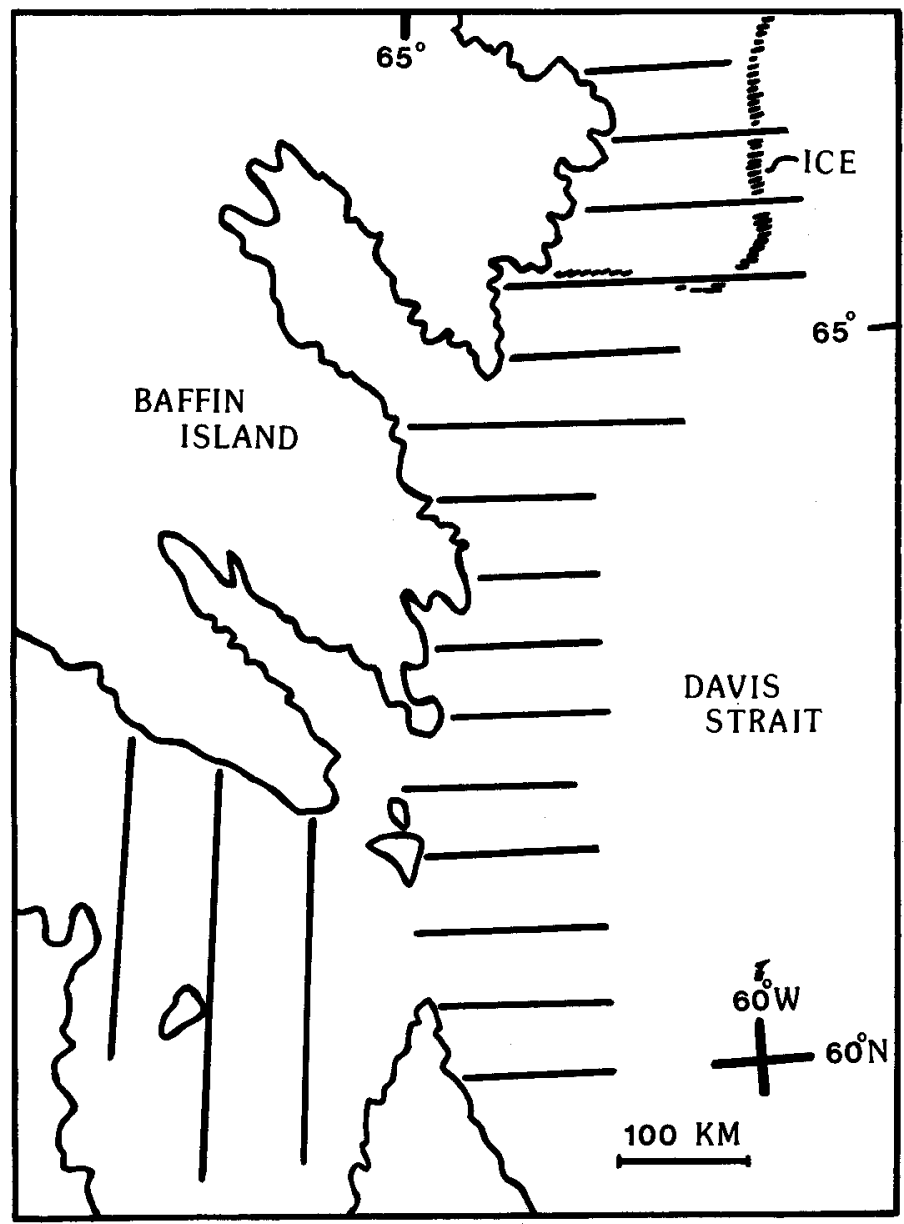

FIG. 3. Locations of aerial transect lines for murres on 14-23 August, and 11-15 and 23-25 September 1977.

\section{METHODS}

The locations and sizes of the seven murre colonies near southern Baffin Island are shown in Figure 2, along with six subdivisions in Hudson Strait and the Labrador Sea and two in western Davis Strait. These eight regions contain the following areas used to calculate total murre numbers: (1) $26100 \mathrm{~km}^{2}$; (2) $22800 \mathrm{~km}^{2}$;(3) $19600 \mathrm{~km}^{2}$;(4) $29800 \mathrm{~km}^{2}$; (5) $45100 \mathrm{~km}^{2}$;(6) $54500 \mathrm{~km}^{2}$;(7) $48000 \mathrm{~km}^{2}$;(8) $59000 \mathrm{~km}^{2}$.

We counted murres during aerial surveys near southern Baffin Island and northern Labrador in the autumn of 1977,1978 and 1979. Survey methods were the same as those described by Orr et al. (1982) and Orr and Parsons (1982), and similar to those of Nettleship and Gaston (1978).

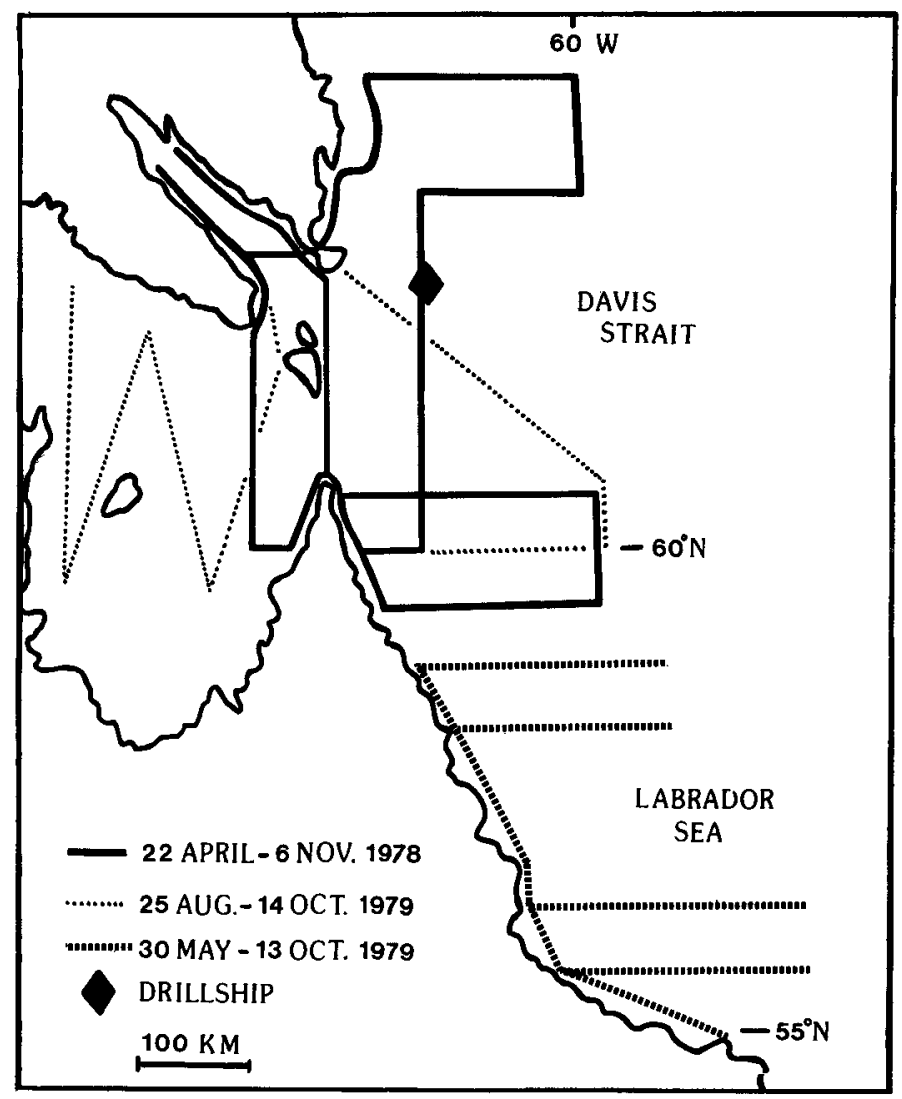

FIG. 4. Locations of aerial transect lines for murres in 1978 and 1979.

Figures 3 and 4 show the transect lines flown in 1977-1979. The 1977 lines were flown once each during the periods 14-23 August, 11-15 September and 23-25 September. These surveys were used to obtain general seabird distributional data in western Davis Strait, while surveys in 1978 and 1979 were flown in Hudson Strait-Ungava Bay, southwest Davis Strait and the northern Labrador Sea, where migrating murres were most dense. In 1978, 18 surveys were flown, each requiring two days to complete, every 7-10 days from 22 April through 5 October, with a final survey on 2-6 November. Single-day surveys were flown in Hudson Strait on 14 and 27 September 1978. In 1979, seven surveys were flown in Hudson and southwest Davis straits and in the northern Labrador Sea (two days each) every 
6-8 days from 25 August through 14 October. We also flew two-day surveys every two weeks in the northern Labrador Sea in 1979 from 30 May to 13 October, in transects along the coast and from the coast out to sea, between $55^{\circ} 30^{\prime}$ and $59^{\circ} \mathrm{N}$. A list of autumn survey dates is found in Appendix A. A total of $12100 \mathrm{~km}$ of transect line was flown in 1977 , $56000 \mathrm{~km}$ in 1978 and $26700 \mathrm{~km}$ in 1979 .

A DeHavilland Twin Otter aircraft was used for surveys north of $59^{\circ} \mathrm{N}$, and a Cessna 337 to the south, equipped, respectively, with GNS-500 Global and CMA 737 Omega navigation systems (Karant, 1976). The aircraft flew 30-35 m above the sea at an average speed of $180 \mathrm{~km} \cdot \mathrm{h}^{-1}$. Observers sat in the right front (co-pilot's) seat, and in the left passenger seat behind the pilot. All birds seen within $200 \mathrm{~m}$ of each side of the aircraft were identified and recorded on cassette tape recorders. (Densities were thus calculated from a $0.4-\mathrm{km}$ wide transect.) To maintain observer efficiency, observation periods were limited to $2 \mathrm{~h}$ (NortonGriffiths, 1976).

Murres can be substantially undercounted by aerial surveyors, particularly in rough seas (MacLaren Marex, 1979), so estimates are minima only. We avoided flying in adverse weather, but sea state did vary between surveys which increased estimate variance. In addition, the left rear observer is in an inferior position for viewing ahead of the aircraft, which results in counts smaller than those of the right front observer, since murres attempting to avoid the aircraft (by diving or flying) are more likely to be missed by a rear observer. In 1977 surveys the right observer saw a total of 1.16 times as many murres as the left observer, and this ratio is applied to correct the counts of the left observer when estimating total numbers.

Finally, daily observations were made from a drillship anchored in southwest Davis Strait $\left(62^{\circ} 11^{\prime} \mathrm{N}, 62^{\circ} 58^{\prime} \mathrm{W}\right)$ from 15 July to 7 October 1979 (Fig. 4). Murres were counted and flight directions recorded during 10-min watches. A total of $194 \mathrm{~h}$ of observations was distributed in 439 watches in July, 370 in August, 313 in September and 42 in October (Orr et al., 1980).

\section{RESULTS AND DISCUSSION}

\section{Migration Initiation}

We did not make systematic flights near colonies, and thus have only incidental data on adult and juvenile attendance at four colonies. Apparently most murres left these colonies from mid- to late August.

Reid Bay. Murres began migrating from the Reid Bay colony (Fig. 2-E) before 19 August in 1977. On that day we counted 100 chicks and several hundred adults on the water below the breeding cliffs, and several groups averaging 6-10 adult-plus-chick pairs $150 \mathrm{~km}$ south: one chick was seen $55 \mathrm{~km}$ further south on the following day. We estimate that there were nearly 175000 adults and chicks in northwest Davis Strait (Table 1) on 19 and 20 August 1977 , undoubtedly a major portion of the Reid Bay population. All flightless migrants from this colony had to travel through extensive pack ice (Fig. 3).

Hantzsch Island. In 1977, adults were abundant within three $\mathrm{km}$ of Hantzsch Island on 14 August, but the first chick (with an adult) was not seen until 18 August, $30 \mathrm{~km}$ south. Two days later, R.G.B. Brown (pers. comm.) sighted 24 chicks near this colony.

Akpatok Island. Only adult murres were seen near Akpatok Island on 21 August 1977 and 25 August 1979, but by 12 September 1977 and 9 September 1979 the breeding ledges were nearly deserted. Prior to 1981, Tuck (1961) made the only shore-based observations of Akpatok Island murres (northern colony) in 1954, and in that year chicks did not begin to fledge until 21 August. In 1981, Gilles Chapdelaine (A.J. Gaston, pers. comm.) found Akpatok hatching dates were about two weeks later than those at Digges Sound in the same year. Both 1954 and 1981 may have been late years, however, judging by the earlier breeding dates for Reid Bay and Hantzsch Island in 1977, and considering Gaston's (1982) observations at Digges Sound in 1980, where chicks began to fledge on 10 August. It is also possible that hatching and fledging dates at Akpatok colonies are consistently later than at other murre colonies in this area (A.J. Gaston, pers. comm.).

TABLE 1. Estimates of Thick-billed Murre mean densities and numbers in northwest and west-central Davis Strait ${ }^{1}$ between 18 August and 5 October 1977 and 1978

\begin{tabular}{|c|c|c|c|c|c|c|c|c|c|}
\hline \multirow{2}{*}{$\begin{array}{l}\text { YEAR } \\
1977 \\
1978 \\
\end{array}$} & \multicolumn{2}{|c|}{ AUGUST } & \multicolumn{6}{|c|}{ SEPTEMBER } & \multirow{2}{*}{$\begin{array}{c}\text { OCTOBER } \\
5 \\
\end{array}$} \\
\hline & $18-20$ & 23 & 7 & 12 & $13-15$ & 19 & $23-25$ & 26 & \\
\hline \multicolumn{10}{|l|}{ Survey detail } \\
\hline $\begin{array}{l}\text { Northwest Davis Strait } \\
\text { Dénsity }\left(\text { birds } / \mathrm{km}^{2}\right) \\
\text { Corrected estimates }\end{array}$ & $\begin{array}{c}3.65 \\
175200\end{array}$ & - & - & $=$ & $\begin{array}{l}0.12 \\
5760 \\
\end{array}$ & - & $\begin{array}{r}0.20 \\
9600 \\
\end{array}$ & - & $\overline{-}$ \\
\hline $\begin{array}{l}\text { West-central Davis Strait } \\
\text { Density (birds/km²) } \\
\text { Corrected estimates }\end{array}$ & $\begin{array}{c}0.39 \\
23010\end{array}$ & $\begin{array}{l}0.05 \\
3422\end{array}$ & $\begin{array}{l}0.10 \\
6844\end{array}$ & $\begin{array}{l}0.08 \\
5475\end{array}$ & $\begin{array}{c}0.72 \\
42480\end{array}$ & $\begin{array}{l}0.06 \\
4106\end{array}$ & $\begin{array}{l}0.02 \\
1180\end{array}$ & $\begin{array}{c}0.28 \\
19163\end{array}$ & $\begin{array}{c}0.01 \\
684 \\
\end{array}$ \\
\hline
\end{tabular}

${ }^{1}$ Areas 7 and 8 delineated in Figure 1

${ }^{2}$ See Methods 


\section{Offshore Migrations}

Davis Strait. Neither aerial nor shipboard observers detected a major southward movement of flightless adults and chicks from Reid Bay, although small concentrations of adults were seen (Table 1). We saw only four chicks in west-central Davis Strait (Region 8) on 17 aerial survey days in 1977, 1978 and 1979. This is far fewer than we would expect from such a large colony (see Hudson Strait results). (R.G.B. Brown [pers. comm.] also found chicks uncommon during the autumn in southwest Davis Strait.) All of the 350 murres seen from the drillship between 21 August and 7 October 1979 were adult-sized and capable of flight. Consequently, we believe that most Reid Bay murres migrated east of our survey area, either south through central Davis Strait en route to Newfoundland, or east to West Greenland.

Flight directions of the murres which passed the drillship in southwest Davis Strait were non-random (chi-square, df $=6, P<0.001$ ), exhibiting a strong easterly component: E (49\%), SE (9\%), S (12\%), SW (5\%), W (2\%), NW (4\%), N (14\%). Murres which continued east would intercept the south Greenland coast, and thus may have joined Lancaster Sound and Greenland murres (Gaston, 1980) wintering there. These flying murres were not chicks of the year, but we do not know if they were sub-adults ( $<4-5$ years of age prior to the breeding season; Birkhead and Hudsor, 1977) or post-breeding adults. Sub-adult murres have migration routes in part distinct from adults in spring (Gaston, 1980). If these murres had bred, many could have been females, since post-breeding males usually accompany chicks from colonies (Swartz, 1966; Gaston and Nettleship, 1981). Additional data are needed on the proportion and status of flying migrants.

Hudson Strait and Labrador Sea. Most sightings of adults and chicks in all years were in the northern Labrador Sea (Region 4) and Regions 1-3 in Hudson Strait, where survey efforts were concentrated (see Methods). A total of 189 chicks was seen in that area in the one-month interval from 6 September to 5 October; most $(83 \%)$ were closely accompanied by a single adult or in close groups of even numbers of chicks and adults.

Chicks were first seen east of Akpatok Island in Hudson Strait on 11 September 1977, 6 September 1978 and 9 September 1979. These early September migrants were probably a significant portion of the Akpatok murres. For example, on 6 September 1978 we estimate (Appendix A) that more than 62000 murres ( 46700 adults, 16000 chicks) were present in Region 3 . This probably represents a large proportion of Akpatok murres moving through this area on a given day during migration, because they apparently travelled rapidly to the Labrador Sea where chicks were first seen on 11 September in 1977, the same day as in Hudson Strait, and on 11 September in 1978 and 16 September in 1979. Therefore, murres from both western and eastern Hudson Strait colonies travel rapidly (up to $40 \mathrm{~km} \cdot$ day $^{-1}$; Gaston, 1982), in the direction of surface currents (Dunbar, 1951), through Hudson Strait and south into the Labrador Sea (Gaston, 1980; this study). We assume that Hantzsch Island murres also went south into the Labrador Sea (see also Gaston, 1980), since only four chicks were seen north or east of this colony.

TABLE 2. Comparison of combined adult and juvenile Thick-billed Murre densities averaged for $3 \mathrm{yr}$ in 2-wk intervals (last $=17 \mathrm{~d}$ ), September and October, Hudson Strait and Labrador Sea subdivisions. Number of surveys in brackets (Data from Appendix A)

\begin{tabular}{llll}
\hline \hline Region & \multicolumn{2}{c}{ September } & October \\
& $1-13$ & $14-27$ & $28-14$ \\
\hline \begin{tabular}{c} 
Hudson Strait \\
\multicolumn{1}{c}{1}
\end{tabular} & $1.14(3)$ & $0.33(4)$ & $0.13(2)$ \\
2 & $0.98(3)$ & $1.74(5)$ & $0.03(1)$ \\
3 & $1.10(5)$ & $0.57(10)$ & $0.42(2)$ \\
\hline Labrador Sea & & & \\
\multicolumn{1}{c}{4} & $0.53(4)$ & $0.48(5)$ & $0.96(3)$ \\
5 & $0.42(1)$ & $1.26(1)$ & $0.74(2)$ \\
6 & $0.64(1)$ & $0.70(1)$ & $1.57(2)$ \\
\hline Hudson Strait vs. & & & \\
Labrador Sea & $\mathrm{P}=0.05$ & $\mathrm{P}=0.50$ & $\mathrm{P}=0.05$ \\
(Mann Whitney U-test) & & & \\
\hline \hline
\end{tabular}

The general timing of murre movements through Hudson Strait into the Labrador Sea, and the separated passage of western and eastern Hudson Strait murres, can be shown by comparing murre densities in Regions 1-3 with those in Regions 4-6 averaged over two-week intervals in September and October (Table 2). In early September, Akpatok murres were significantly more abundant in Hudson Strait than in Labrador Sea subdivisions (Mann Whitney U-test, Siegel, 1956). In the final two weeks of September, there was no difference between mean densities of murres in Hudson Strait and the Labrador Sea (Table 2), suggesting that there were roughly equal numbers of Akpatok murres in the Labrador Sea, and Digges (and Coats Island) murres in eastern Hudson Strait. The later passage of these western Hudson Strait murres reflects the additional $600 \mathrm{~km}$ they must travel (Fig. 2). A mid-September arrival of Digges murres in Regions 1-3 is also consistent with Gaston's (1982) 1980 results. Digges murres similarly passed rapidly through eastern Hudson Strait to the Labrador Sea, where mean densities were significantly greater than those in Hudson Strait between 28 September and 14 October (Table 2). Murre numbers continued to increase in Region 6, the most southerly region, at least until mid-October when our surveys terminated (see Appendix A). These murres begin to arrive in waters around Newfoundland in early November (Tuck, 1961; Brown et al., 1975; Gaston, 1980).

In conclusion, murres exploiting productive but short arctic summers for breeding (Tuck, 1961; Gaston and Nettleship, 1981) are able to begin migrating in the autumn before chicks can fly, and before pack ice forms, by swim- 
ming in the direction of prevailing surface currents (Hudson Strait and Labrador Sea) and/or toward nearby areas of permanent open water (Baffin Island to southwest Greenland). Such a form of migration may also be energetically more efficient than flying, perhaps particularly advantageous to the still-growing chicks.

\section{ACKNOWLEDGEMENTS}

Logistic support was provided by Esso Resources Canada Ltd., Aquitaine Co. of Canada Ltd. and Canada Cities Services Ltd. (Davis Strait surveys) and by Petro-Canada and the oil industry's Labrador group (Labrador Sea surveys), as part of the Eastern Arctic Marine Environmental Studies and Offshore Labrador Biological Studies programs, respectively. Several observers besides the authors contributed to these surveys, including J. Booth, J. Brownlie, I. Cameron, S. Johnson, J. Parsons, C. Paton, J. Piatt, M. Purdy, V. Sinclair, P. Stewart and N. Williams. E. Peters, E. Joamie, B. Etooangat and N. Onalik made most of the drillship observations. We particularly thank pilots $P$. Doyle, J. MacDonald, R. Michelin, D. Roy and F. Fitzpatrick for their expert flying. I. Brown provided computer assistance, and R.G.B. Brown, A.J. Erskine, A.J. Gaston, K. Puckett and N.A.M. Verbeek made helpful comments on the manuscript.

\section{REFERENCES}

BIRKHEAD, T.R. and HUDSON, P.J. 1977. Population parameters for the common guillemot, Uria aalge. Ornis Scandinavica 8:145-154.

BIRKHEAD, T.R. and TAYLOR, A.M. 1977. Moult of the guillemot Uria aalge. Ibis 119:80-85.

BROWN, R.G.B., NETTLESHIP, D.N., GERMAIN, P., TULL, C.E. and DAVIS, T. 1975. Atlas of Eastern Canadian Seabirds. Ottawa: Canadian Wildlife Service. $220 \mathrm{p}$.

DUNBAR, M.J. 1951. Eastern Arctic Waters. Fisheries Research Board of Canada Bulletin No. 88. 131 p.

GASTON, A.J. 1980. Populations, movements and wintering areas of Thick-billed Murres (Uria lomvia) in eastern Canada. Canadian Wildlife Service Progress Note No. $110.10 \mathrm{p}$.

1982. Migration of juvenile Thick-billed Murres through Hudson Strait in 1980. Canadian Field-Naturalist 96:30-34. and NETTLESHIP, D.N. 1981. The Thick-billed Murres of Prince Leopold Island - A Study of the Breeding Ecology of a Colo- nial High Arctic Seabird. Canadian Wildlife Service Monograph No. 6. $350 \mathrm{p}$.

KARANT, M. 1976. The global navigation system. APOA Pilot 10:59-61.

MacLAREN MAREX INC. 1979. A field comparison of aerial and shipboard marine bird surveys in Labrador. Prepared for Department of Supply and Services and Canadian Wildlife Service, Dartmouth, Nova Scotia. 23 p. [Available from Canadian Wildlife Service, Bedford Institute of Oceanography, P.O. Box 1006, Dartmouth, Nova Scotia B2Y 4A2.]

NETTLESHIP, D.N. 1977. Seabird resources of eastern Canada: status, problems and prospects. In: Mosquin, T. and Suchal, C. (eds.). Proceedings of the Symposium on Canada's Threatened Species and Habitats. Canadian Nature Federation Special Publication No. 6. 96-108.

and GASTON, A.J. 1978. Patterns of pelagic distribution of seabirds in western Lancaster Sound and Barrow Strait, Northwest Territories, in August and September 1976. Canadian Wildlife Service Occasional Paper No, 39. 40 p.

NORTON-GRIFFITHS, M. 1976. Further aspects of bias in aerial census of large mammals. Journal of Wildlife Management 40:368-371.

ORR, C.D., GILLIS, D.J. and VALDRON, L.G. 1980. Snow Buntings, Lapland Longspurs and other passerines in Davis Strait and Labrador Sea, 1977-1979. Canadian Field-Naturalist 94:185-187.

ORR, C.D., WARD, R.M.P., WILLIAMS, N.A. and BROWN, R.G.B. 1982. Migration patterns of Red and Northern Phalaropes in southwest Davis Strait and in the northern Labrador Sea. Wilson Bulletin 94:303-312.

ORR, C.D. and PARSONS, J.L. 1982 (in press). Ivory Gulls and ice edges in Davis Strait and the Labrador Sea. Canadian Field-Naturalist.

SALOMONSEN, F. 1950. The Birds of Greenland. Copenhagen: Ejnar Munksgaard. $604 \mathrm{p}$.

1967. Fuglene pa Grónland. Copenhagen; Rhodos. 340 p.

1979. Marine birds in the Danish Monarchy and their conservation. In: Bartonek, J.C. and Nettleship, D.N. (eds.). Conservation of Marine Birds of Northern North America. U.S. Fish and Wildlife Service Research Report No. 11. 267-287.

SIEGEL, S. 1956. Nonparametric Statistics for the Behavioral Sciences. New York: McGraw-Hill Book Company. 321 p.

SWARTZ, L.G. 1966. Sea-cliff birds. In: Wilimovsky, N.J. (ed.). Environment of the Cape Thompson Region, Alaska. U.S. Atomic Energy Commission Clearing House for Scientific and Technical Information, Springfield, Virginia. $1250 \mathrm{p}$.

TUCK, L.M. 1961. The Murres. Canadian Wildlife Service Monograph No. $1.260 \mathrm{p}$.

TULL, C.E., GERMAIN, P. and MAY, A.W. 1972. Mortality of Thickbilled Murres in the West Greenland salmon fishery. Nature 237:42-44. 
APPENDIX A. ESTIMATES OF THICK-BILLED MURRE DENSITIES AND NUMBERS IN REGIONS 1 - 6 BETWEEN 22 AUGUST - 6 NOVEMBER, 1977-1979

\begin{tabular}{|c|c|c|c|c|c|c|c|c|c|c|c|c|c|c|c|c|c|c|c|c|c|c|c|c|c|c|c|c|c|c|c|c|}
\hline & Year & & August & & & & & & & & & & & Septer & ember & & & & & & & & & & & & & October & & & Novenber & \\
\hline RVEY DETALL & $\begin{array}{l}1977 \\
1978 \\
1999\end{array}$ & $22 ?$ & $\begin{array}{lll}23 & & \\
2 & 22 & 23\end{array}$ & 4 & 5 & 6 & 7 & 9 & 11 & 12 & 14 & 15 & 15 & 16 & 17 & 19 & 20 & 22 & 23 & 25 & 25 & 26 & 27 & 29 & 30 & 4 & 5 & 12 & 13 & 14 & & \begin{tabular}{|c} 
Totals \\
Corrected \\
Estimates)
\end{tabular} \\
\hline $\begin{array}{l}\text { jian } 1 \\
\text { nsity (birds. } \mathrm{km}^{-2} \text { ) } \\
\text { imales } \\
\text { mected Estimates }\end{array}$ & & 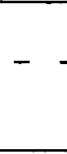 & --- & - & - & - & - & $\begin{array}{rl}1.44 & 0 \\
37598 & 1 \\
43614 & 2\end{array}$ & $\begin{array}{l}0.07- \\
1828\end{array}$ & $\begin{array}{r}1.91 \\
4970 \\
57849 \\
\end{array}$ & $\begin{array}{l}0.12 \\
3133 \\
364 \\
\end{array}$ & - & $\begin{array}{c}0.01 \\
272 \\
316 \\
\end{array}$ & - & - & - & $\begin{array}{r}-1 \\
16 \\
19\end{array}$ & $\begin{array}{c}0.65 \\
16972 \\
19688\end{array}$ & - & - & - & $\begin{array}{r}-\quad 0 \\
14 \\
16\end{array}$ & $\begin{array}{ll}0.54 & 0 \\
14099 & 54 \\
16355 & 63\end{array}$ & $\begin{array}{l}0.21 \\
5483 \\
6360\end{array}$ & - & & $\begin{array}{r}-\quad 0.05 \\
1306 \\
1515\end{array}$ & 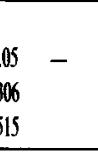 & - & - & - & \\
\hline $\begin{array}{l}\text { mates } \\
\text { rected Estimates }\end{array}$ & & - & --- & - & - & - & - & $\begin{array}{r}0.74 \\
17570 \\
20381\end{array}$ & - & $\begin{array}{r}1.22 \\
27838 \\
32292 \\
\end{array}$ & $\begin{array}{l}0.50 \\
114091 \\
132341\end{array}$ & $\begin{array}{r}5.60 \\
127781 \\
186226 \\
\end{array}$ & $\begin{array}{l}0.24 \\
5476 \\
6352 \\
\end{array}$ & - & - & - & $\begin{array}{r}-1 \\
39 \\
40\end{array}$ & $\begin{array}{r}1.74 \\
39703 \\
46055\end{array}$ & - & $\begin{array}{r}0.61 \\
13919 \\
16146 \\
\end{array}$ & - & - & - & $\begin{array}{l}0.03 \\
761 \\
883\end{array}$ & - & - & - & - & - & - & - & 3569 \\
\hline $\begin{array}{l}\text { ensity (birds. } \mathrm{km}^{-2} \text { ) } \\
\text { stimates } \\
\text { orrected Estimates }\end{array}$ & & $\begin{array}{ll}0.03 & 0 . \\
589 & 56 \\
683 & 66\end{array}$ & $\begin{array}{l}0.29-- \\
3691 \\
6602\end{array}$ & - & - & $\begin{array}{r}2.75 \\
53968 \\
62603 \\
\end{array}$ & $\begin{array}{l}1.42 \\
19626 \\
22766 \\
\end{array}$ & $\begin{array}{l}0.09 \\
1766 \\
2248 \\
\end{array}$ & $\begin{array}{r}-\quad 0.06 \\
157 \\
182 \\
\end{array}$ & $\begin{array}{cc}01.14 \\
74 & 22373 \\
26 & 25953 \\
\end{array}$ & $\begin{array}{l}0.06 \\
1178 \\
1366\end{array}$ & $\begin{array}{l}0.40 \\
7850 \\
9106 \quad 1 \\
\end{array}$ & $\begin{array}{r}0.64 \\
12560 \\
14570 \\
\end{array}$ & - & $\begin{array}{r}-0.06 \\
1178 \\
1366 \\
\end{array}$ & $\begin{array}{ll}6 & 1.57 \\
78 & 30811 \\
66 & 35741\end{array}$ & $\begin{array}{r}1 \\
22 \\
26\end{array}$ & $\begin{array}{r}1.15 \\
22569 \\
26180\end{array}$ & - & $\begin{array}{r}-0.15 \\
2944 \\
3415\end{array}$ & $\begin{array}{l}0.25 \\
1906 \\
5691\end{array}$ & $\begin{array}{cc}0.46 & 0 \\
9028 & 19 \\
1042 & 22\end{array}$ & $\begin{array}{rr}0.99 & 0 . \\
19429 & 35 \\
25338 & 41\end{array}$ & $\begin{array}{l}0.18 \\
3349 \\
4117 \\
\end{array}$ & $\begin{array}{l}1 \\
12 \\
14\end{array}$ & $\begin{array}{r}0.65 \\
12756 \\
1497 \\
\end{array}$ & - & - & - & -1 & $\begin{array}{l}0.04 \\
791 \\
918\end{array}$ & 272758 \\
\hline $\begin{array}{l}\text { eginan } 4 \\
\text { ensity (birds:km }{ }^{-2} \text { ) } \\
\text { stimates } \\
\text { orrected Estimates }\end{array}$ & & {$\left[\begin{array}{l}0.04 \\
1593 \\
1848\end{array}\right.$} & --- & - & - & $\begin{array}{r}0.24 \\
9560 \\
11000 \\
\end{array}$ & $\begin{array}{r}1.69 \\
67319 \\
78000\end{array}$ & $\begin{array}{r}-\quad 0 \\
2 \\
2\end{array}$ & $\begin{array}{ll}0.06 & 0.1 \\
3390 & 637 \\
2772 & 739\end{array}$ & $\begin{array}{l}16 \\
73 \\
93\end{array}$ & - & - & 6 & $\begin{array}{r}1.51 \\
60149 \\
69773 \\
\end{array}$ & $\begin{array}{r}-0.03 \\
1195 \\
1386\end{array}$ & $\begin{array}{ll}33 & - \\
86 & -\end{array}$ & - & $\begin{array}{r}-\quad 0 \\
239 \\
2 m\end{array}$ & $\begin{array}{ll}0.60 & 0.06 \\
23900 & 2390 \\
2724 & 272\end{array}$ & $\begin{array}{l}106- \\
390 \\
722\end{array}$ & $\begin{array}{r}0.24 \\
9560 \\
11090 \\
\end{array}$ & - & - & $\begin{array}{r}0 . \\
123 \\
143 \\
\end{array}$ & \begin{tabular}{l|l|l}
0.31 & \\
2349 & 3. \\
4325 & 4 \\
\end{tabular} & $\begin{array}{r}0.90 \\
35851 \\
41587 \\
\end{array}$ & - & - & & $\begin{array}{r}1.68 \\
66921 \\
77628\end{array}$ & $\left|\begin{array}{r}-0.06 \\
2390 \\
272\end{array}\right|$ & 350250 \\
\hline $\begin{array}{l}\text { egion } 5 \\
\text { ensity (birds.km-23) } \\
\text { stimates } \\
\text { orrected Estimates' }\end{array}$ & & - & --0 & - & $\begin{array}{r}0.42 \\
18935 \\
21965\end{array}$ & - & - & - & - & - & - & - & - & - & - & - & $\begin{array}{r}1.26 \\
56865 \\
65894\end{array}$ & - & - & - & - & - & - & - & - & - & $\begin{array}{r}0.14 \\
6312 \\
7322\end{array}$ & 142 & $\begin{array}{l}1.34 \\
60411 \\
70007\end{array}$ & - & -- & 165258 \\
\hline $\begin{array}{l}\text { legiona } 6 \\
\text { Ensity (birds } \cdot \mathrm{km}^{-2} \text { ) } \\
\text { istimates } \\
\text { Comected Estimates }\end{array}$ & & - & $-0-$ & $\begin{array}{r}0.64 \\
34960 \\
40554 \\
\end{array}$ & - & - & - & - & - & - & - & - & - & 38 & $\begin{array}{l}0.70- \\
.8253 \\
14373\end{array}$ & - & - & - & - & - & - & - & - & - & - & $\begin{array}{r}0.9 \\
5399 \\
6259 \\
\end{array}$ & $\begin{array}{l}0.99- \\
3999 \\
2592\end{array}$ & $\begin{array}{r}2.15 \\
1171102 \\
135838 \\
\end{array}$ & - & - & - & 283357 \\
\hline mected Essimates) & & & 6602000 & 40554 & 21965 & 736931 & 1008366 & 660134 & & 19116004 & & & 2133869 & & $4373 \quad 2752$ & & 6889491 & & & $772 \quad 19561$ & 16781 & & & & & & & & & & & 1506643 \\
\hline
\end{tabular}

'Correction factor applied to compensate for birds missed by observer $L$ are from 1977 surveys: 1.16 (See Methods). 